$£ 635,000$ in 1963-64. In reply to a further question, $\mathrm{Mr}$. Hogg stated that members of the Committee on AudioVisual Aids in teaching and research would be visiting the United States in April, and he understood their itinerary included visits to universities, colleges of education and technological colleges. The Committee's terms of reference were drafted to cover fields thought to offer the greatest immediate potential scope for such aids, and to achieve a reasonably early report, but there was no intention to prejudice possible use of audio-visual aids in other fields of higher education. Four American professors in Britain had already given evidence to the Committee.

New Chair of Building at University College, London

A NEW chair is to be established at the Bartlett School of Architecture at University College, London. This chair has been made possible by financial support from the London Master Builders Association. The new professor, who it is hoped will be appointed before October 1964, will be engaged in research into the economics and organization of the building industry. The Bartlett School of Architecture provides three-year courses leading to a B.A. or B.Sc. degree. These courses are taken by both future architects and men who intend to work in the building industry. The new professor will contribute to the teaching of these students, who are educated side by side. He will also teach postgraduate students who are following advanced studies in the economics and organization of the building industry, and who may have taken first degrees in architecture, economics or civil engineering. His research students will include men from a variety of disciplines related to building and urban development. The establishment of this chair follows a programme initiated at University College, whereby postgraduate architectural students undergo a period of training with building contractors in the London area. It is expected that the new chair will have an important effect in bridging the gulf between the professions and the industry in building.

\section{Scientific and Technical Information in the U.S.S.R.}

A REPORT issued by the Information Division of the Department of Scientific and Industrial Research describes briefly the visit to Moscow and Leningrad of a delegation of the Department and the Association of Special Libraries and Information Bureaux (Aslib) during June 7-24, 1963 (Information in the Soviet Union. Pp. iv +44. London: Library, Department of Scientific and Industrial Research, 1964. Gratis). The report includes notes on scientific libraries and information centres visited, and comments on the relevance of what was seen to corresponding activities in the United Kingdom. Appendixes to the report give more detailed information on the institutions visited. A main impression derived was the sense of urgency and importance accorded in the U.S.S.R. to all aspects of the preparation, publication and dissemination of the results of scientific research and development and the flow of technical information to industry. Present arrangements are under review and a long-term programme of research into scientific documen. tation has been started. The organized supply of scientific and technical information is treated as an essential part of the centralized control of research and development in support of national plans for industrial production. A State Committee for the Co-ordination of Scientific Research has a headquarters of information department and is advised by a Special Scientific Council on Information Problems. There is an all-union Institute for Scientific and Technical Information which has as its main tasks: the preparation of abstracts in the natural and applied sciences (excluding architecture, building, medicine and agriculture); the organization of instruction in scientific information in universitios and institutes; and the organization and co-ordination of research into the rational organization of information activities, and the mechanical and automatic means of processing and retrieving scientific information. Its work in the production of physics abstracts, postgraduate instruction in the use of libraries and in scientific information and machine translation is of special interest to the United Kingdom. Many of its permanent staff of 2,500 are highly qualified scientists.

\section{Scientific Research in France}

The report of the National Centre for Scientific Research, Paris, October 1962-October 1963, is a massive volume of more than 500 pages (Rapport d'Activité, Octobre 1962-Octobre 1963. Pp. 510. Paris: Centre National de la Recherche Scientifique, 1963). Following a brief introduction, the first part deals with the budget, which for 1963 at 282 million francs represents an increase of 29 per cent on 1962; of this total, 48.1 million francs represents fresh resources, and $16 \cdot 2$ million francs salary increases, etc. The staff of the Centre has accordingly been increased from 908 to 1,052 , of whom 356 are research workers and 700 technicians. Expenditure on staff was 206 million francs, compared with 163 million francs in 1962. The total number of research workers supported rose by $9 \cdot 2$ per cent to 4,123 , of whom 145 are directors or assistant directors of research centres and 56 directors of research contracts; of this total, 820 are engaged in the human sciences and 3,288 in the exact or natural sciences (physical chemistry. 343; organic chemistry, 305; biological chemistry, 270; nuclear physics, 251; zoology and animal biology, 213; electronics. electricity and mag. netics, 205; experimental pathology and therapeutics, 193; mineral chemistry, 187; physiology, 178). Grants for materials totalled 18 million francs and for equipment 20 million francs; and for international missions, $5 \cdot 6$ million francs. The second part of the report deals with the work of the National Committee for Scientific Research and describes briefly the activities of the various research groups. The third part, occupying some 300 pages, deals with the work of the laboratories and research centres maintained by the National Centre, including notes on research in progress and, occasionally, lists of publications. There are also brief reports from the several scientific commissions.

\section{Biology of the Antarctic Seas}

LEADING marine biologists present the results of recent work in antarctic waters in Biology of the Antarctic Seas, the first volume of a new series of books called the "Antarctic Research Series" which will appear in April. The book will be published by the American Geophysical Union, 1515 Massachusetts Avenue, N.W., Washington, D.C., 20005. The series is funded by a grant from the U.S. National Science Foundation, and future volumes will include all phases of antarctic research. Volumes now being planned are in the fields of glaciology, meteorology, aeronomy, geology, pedology and botany: Further information can be obtained from the American Geophysical Union.

\section{Food Preservation Quarterly}

A RECEnt issue of Food Preservation Quarterly (23, No. 3; September 1963. Division of Food Preservation, C.S.I.R.O., Australia) contains the following original papers: "Trends in Citrus Products in the U.S.A.", by J. F. Kefford; "Use of the Maturometer for Quality Grading of Peas", by B. K. Nortje, C. J. B. Smit and K. J. Kotze; and "Experimental Shipments of Apples and Pears", by E. G. Hall. Also reported on is the Food Technology Exhibition held at the Division's research laboratories at North Ryde on July 4 and attended by about 125 technologists. This included displays of a device for rapidly removing peas from their pods with 